hebben. Alweer een roldingend bewijs, dat alleen de werkzame en vindingrijke man ook de man is van dat welslagen, hetwelk alleen de onkundige en kortzichtige van het toeval wacht.

De man ran arbeid oogst voorspoed en is een heilzaam voorbeeld voor anderen, de speler daarentegen verliest gewoonlijk wat hij won en demoraliseert door zijn aarivankelijk succès geheel het volk.

P. N. M.

\title{
DE INVLOED VAN BETERE ARBEIDERSWONINGEN OP DE GEZONDHEID DER BEWONERS.
}

Als aanhangsel van mijne opstellen over den bouw van arbeiderswoningen in dit tijdschrift geleverd, wenseh ik thans eenige bijzonderheden mede to deelen, ontleend aan een verslag door den secretaris der Metropolitan Association for Improving the Dwellings of the Industrious Classes in Londen, dezer dagen uitgebragt, nopens den invloed van de woningen van een der voornaamste vereenigingen van dien aard in de metropolis gevestigd, met betrekking tot de gezondheid en zedelijkheid der bewoners. De schạarschbeid van feiten op sanitair gebied voorhanden en de zeer gedetailleerde en vertrouwbare bijzonderheden in dit verslag medigedeeld, hebben het mij nuttig doen voorkomen, ze ook ouder de oogen van de lezers van de Economist te brengen.

Het onderzoek loopt over een aantal van 1060 woningen in 12 blokken over verschillende gedeelten der stad verspreid, die ruim 53000 personen huisvesten; het omrat een tijdvak van 8 jaren, eindigende net Mart 1874 en heeft onder medewerking van den bekenden Dr. Guy plaats gehad.

De ziekten, waaraan de bewoners gedurende dien tijd hebben geleden en die als oorzaken van den dood moeten worden beschouwd, worden overeenkomstig de officieele statistieken, in zekere groepen gerangschikt. Daaruit blijkt dat van 1867-1874 overleden zijn aan zoogenaamde zymotische (besmettelijke, miasmatische) ziekten 91 , aan ziekten van algeweenen aard (waterzucht, kanker, tering enz.) 106, aan plaatselijke (long-, hartanndoeningen) 213 , aan ziekten van de ontwikkeling (levenzzwakte, 
tanden) 41 , aan gewelddudige invloeden (ongelukken) 6; niet geconstateerd 3 gevallen; in het geheel 462 sterfyevallen.

Indien men de gemiddelden per 1000 van elke dier groepen over 7 jaren bij de bewoners der betere woningen vergelijkt met die van de overige bewoners der metropolis, dan verkriggt men de volgende nitkomsten.

Gemiddelle sterfte per 1000 in de betere woningen. In de inetropolis.

aan Zymotische ziekten . . . . . 209 . . . . . 2444

"Ziekten van algem. aard . . . . 248 . . . . . . . 191

"Plaatselijke aandoeningen . . . 451 . . . . . 418

" Ziekten der ontwikkeling . . . 90 . . . . . . 113

"Gewelddadige invloeden. . . . 2 . . . . . . 34

De gunstige sterfteverhouding aan zymotische en ontwikkelingsziekten komt bierbij vooral uit bij de bewoners der betere woningen.

Nog gunstiger treedt dat versehil voor den dag bij eene vergelijking van de sterfteverhouding per 1000 aan alle ziekten onder de bewoners van de verbeterde woningen en die van de bevolking van Engeland, van de metropolis, van hare verschillende districten en van de voornaamste steden van Engeland over een tijdvak van 5 jaren.

\section{Er stierven}

$\begin{array}{lllll}1867 & 1868 & 1869 & 1870 & 1871\end{array}$

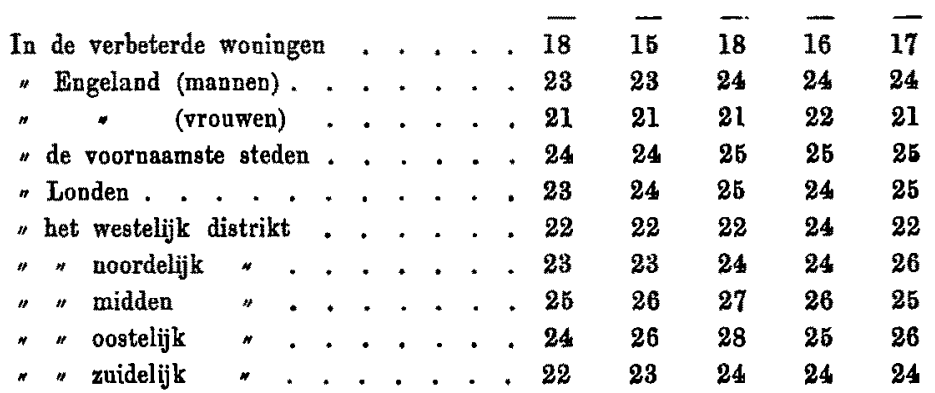

Wij zien hieruit, dat de verhouding in het gunstigste jaar (1868) voor de bewoners van de betere woningen tegenover de gemengde bevolking van Engeland oen voordeel pan 7 p. m. oplevert on in de ongunatige jaren (1867 en 1869) van $4 \mathrm{p}$. m. Stellen we nu, ten opzigte van de voornaumste steden, van Londen en van zijne districten, de meest ongunstige tegenover de meest gunstige sterfteverhouding, dan krijgen wij een verschil ten gunste der betere woningen van $26-15=11$; van $25-18=7$; van $28-18=10$.

Ten einde nu de tegenwerping te ontgaan, dat do bevolking ran de modelwoningen eene andere is wat den leeftijd betreft dau 
de overige, henft de vorslaggever een stat opgemaikt van de burolking dier woningen boneden en boren de 10 jaren. Daaruit blijkt, dat van elke 1000 bewoners 330 beneden, en 670 boven dien leeftijd wareu, terwijl die verhouding bij de bevolking van Londen 237 beneden en 763 boven de 10 jaren was.

Wij zien hieruit, dat de verhouding der zeer jeugdige berolking in de modelwoningen veel grooter is dan die in de metropolis. Ofschoon die grootere verhouding eener zeer jeugdige bevolking op de algemeene sterfte ongunstig moet inwerken, ontwaart men echter bij dat deel der berolking in de modelwoningen het tegenovergestelde, indien het vergeleken wordt met dezelfde categorie der bevolking van Londen. De onderzoekingen daromtrent hebben toch geleerd, dat de gemiddelde sterfte van kinderen beneden de 10 jaren in de betere woningen 24 p. m., voor de gehuele bevolking van Londen $48 \mathrm{p}$. m. was. Nu zou men kunnen vragen: ligt dit ook in eene geringere prodactiviteit der bevolking van de codelwoningen? Maar dan is het antwoord: de geboorteverhouding was daar in de laatste 7 jaren 36 p. m. en in Londen slechts 34.5 p. m.

Terwijl de sterfteverhouding rau de geheele bovolking van Ionden (alle leeftijden door elkaar) in de laatste 8 jaren meer dan 24 p. m. bedroeg, was die bij de bewoners der modelwoningen slechts 14 p. m. Behalve in de gezonde woning moet de gunstigere verhouding ook gezocht worden in de soort van bewoners, die als het ware de keur der arbeidersbevolking uitmaken. Vooreerst toch mag men annemen, dat zij die naar dergelijke woniugen dingen, zich onderscheiden van de massa, maar ten andere worden de bewoners door de directie met zorg gekuzen uit een lange lijst van candidaten en wordt zoowel op zedelijkheid als op gezondheid bijzonder gelet (*).

De verhouding der bewoners boven de 60 jaren tegenover de bevolking van Londen boven dien leeftijd, is zeer gunstig : $32: 62$ Dasrentegen is de talrijkheid van bet gezin miuder gunstig; in de modelwoningen 4.91, in geheel Engeland 4.41.

Vit de opgesomde verhoudingen resulteert alzoo:

10. dat de berolking der modelwoningen een zeer jeugdige is;

$2^{\circ}$. dat zij in omvang is toenemend;

3o. dat het kleine getal bewoners boven de 60 jaren, onder welke uit den aard der zake eene boogere sterfteverhouding zal

(*) Verg. het Naschrift der Redactie, Economist 1874, pag. 720. RED. 
heerschen, in zeker opzigt het hooger cijfer van de bevolking beneden 10 jaren vereffent;

40. maar dat, in aanmerking nemende den overmaat van jonge kinderen, het lage sterftecijfer een sprekend bewijs is pan degezondbeid en de kracht der bevolking dezer woningen.

De besparing aan ziekten en sterfte moet derhalve groot zijn, als wij aannemen mogen, dat tegon één persoon die sterft, er 2 door eene ernstige ziekte worden aangetast. Hoeveel meer levensgenot en welvaart worden hierdoor niet gesmaakt?

Nog een ander materieel voordeel leveren deze woningen op, namelijk de betrekkelijk geringe ruimte die ze beslaan, in weerwil van de aanzienlijke ruimte ingenomen door de speelplatatseu en de inrigtingen voor de ventilatio. De verhouding van de bevolking dier huizen tot de oppervlakte overtreft viermalen die van de bevolking der metropolis op eene gelijke oppervlakte. Westminster, het digtst bevollst, bevat 235 personen per acre, terwijl de gronden van de Metropolitan Association worden ingenomen door gemiddeld 1.140 personen per acre. Van de 156,732 vierk. voeten, die de gebouwen der vereeniging beslaau, zijn slechts 74,620 v. v. bebouwd en waren daar 817 gezinnen in huizen 5, 6 en 7 verdiepingen hoog. En toch, in weerwil van die opeenhooping in de meestal digtst bevolkte gedeelten der stad waar de gebouwen staan, steekt de gezondheids- en sterf teverhouding in die huizen zoo gunstig. af bij de bewoners van het overige deel van Londen.

Wel een bewijs, dat ook de kazernewoniug, zelfs in eene ongunstige ongeving geplaatst, aan de gezondheid harer bewoners bevorderlijk kan zijn, indien de voorschriften der gezondheidsieer en der moraliteit naar behooron worden inachtgenomen.

S. Sr. C. 